\title{
Conventional TESE technique: A short review and a single-centre experience in 9 years
}

\author{
Dinko Hauptman ${ }^{1}$, Tvrtko Hudolin ${ }^{1,2}$, Zoran Zimak ${ }^{1}$, Tomislav Kulišr, ${ }^{1,2}$, Davor Ježek², \\ Željko Kaštelan ${ }^{1,2}$ \\ ${ }^{1}$ University Hospital Centre Zagreb, Department of Urology \\ ${ }^{2}$ University of Zagreb, School of Medicine
}

OPEN ACCESS

Correspondence:

Dinko Hauptman dinko.hauptman@kbczagreb.hr orcid.org/0000-0001-7151-6512

This article was submitted to RAD CASA - Medical Sciences as the original article

Conflict of Interest Statement: The authors declare that the research was conducted in the absence of any commercial or financial relationships that could be construed as a potential conflict of interest.

Received: 21 April 2021 Accepted: 28 April 2021 Published: 15 June 2021

Citation: Hauptman D, Hudolin T, Zimak Z, Kuliš $T$, Ježek D, Kaštelan Ž. Conventional TESE technique: A short review and a single-centre experience in 9 years RAD CASA - Medical Sciences. 547=54-55 (2021): 70-74 DOI: https://dx.doi. org/10.21857/9xn31cojjy

Copyright (C) 2021 Hauptman D, Hudolin T, Zimak Z, Kuliš T, Ježek D,

Kaštelan Ž. This is an open-access article distributed under the terms of the Creative Commons Attribution License (CC BY). The use, distribution or reproduction in other forums is permitted, provided the original author(s) and the copyright owners(s) are credited and that the original publication in this journal is cited, in accordance whit accepted adacemic practice. No

use, distribution or reproduction is permitted which does not comply with

\begin{abstract}
:
Infertility is defined as the inability of a sexually active, non-contraceptive couple to achieve spontaneous pregnancy within one year (Word Health Organisation). It is estimated that there are $15-20 \%$ of infertile couples, and this number is increasing, making infertility a major socio-demographic global problem. In the past, female factors were thought to be the main causes, but today we know that male infertility accounts for about $50 \%$ of cases. Therefore, simultaneous treatment of both sexes is recommended.

The most severe condition of male infertility is azoospermia, which occurs in the general population in $1 \%$, while in infertile male populations it occurs in $10-20 \%$ of cases. Azoospermia can be obstructive (OA) and non-obstructive (NOA). Among various treatment options for azoospermia, testicular biopsy (TESE) provides the best chance of sperm retrieval. TESE can be done by classical (conventional, open) approach or using an operating microscope, microsurgical TESE (mTESE). mTESE is reserved for the most complex patients with genetic disorders or previously sperm retrieval failure during conventional TESE procedure.
\end{abstract}

KEYWORDS: infertility, azoospermia, open testicular biopsy (TESE), microsurgical TESE (mTESE), cryopreservation, urology

\section{SAŽETAK:}

KONVENCIONALNA TESE: KRATKI PREGLED I DEVETOGODIŠNJE ISKUSTVO JEDNOG CENTRA

Neplodnost je nemogućnost postizanja spontane trudnoće seksualno aktivnog para koji ne koristi kontracepciju u roku od jedne godine (Svjetska zdravstvena organizacija). Procjenjuje se da ima $15-20 \%$ neplodnih parova i taj se postotak povećava, što neplodnost čini važnim, globalnim sociodemografskim problemom. U prošlosti se smatralo kako je ženska neplodnost češća, ali danas znamo da polovicu slučajeva čine muškarci. Stoga se preporučuje istovremena obrada i liječenje oba spola. Najteži oblik muške neplodnosti je azoospermija, koja se u općoj populaciji javlja u $1 \%$ muškaraca, dok se u neplodne muške populacije javlja u 10-20\% slučajeva. Azoospermija može biti opstruktivna (OA) i neopstruktivna (NOA). Među različitim mogućnostima liječenja azoospermije, biopsija testisa (TESE) pruža najbolje šanse za pronalazak spermija. TESE se može izvesti klasičnim (konvencionalnim, otvorenim) pristupom ili uporabom operacijskog mikroskopa, mikrokirurška TESE (mTESE). mTESE se koristi kod najsloženijih pacijenata s genetskim poremećajima ili prethodno neuspjelim pronalaženjem spermija tijekom uobičajenog TESE postupka.

KLJUČNE RIJEČI: neplodnost, azoospermija, otvorena biopsija sjemenika (TESE), mikrokirurška TESE (mTESE), krioprezervacija, urologija 
Infertility in men, as defined by the World Health Organization, is a condition in which a man has not conceived a child for 12 months (without the use of contraceptive). It is estimated that in the Republic of Croatia, as in other European Union countries, $15-20 \%$ of couples are infertile or have problems conceiving, and male infertility is responsible for $20-50 \%$ of cases. The most severe form of infertility is the complete absence of sperm in the semen, which is defined as azoospermia, and occurs in the general population in $1 \%$, while in infertile men it occurs in 10 $20 \%$ of cases. ${ }^{1-3}$ Azoospermia can be obstructive (OA) and nonobstructive (NOA), the latter usually has a more severe form. ${ }^{1}$ The etiology of male infertility is unclear and although there are some diseases, some environmental factors, as well as some eating and psychological disorders that may be associated with infertility, in $70-90 \%$ of cases it is unknown ${ }^{4}$. A significant number of patients $(30-40 \%)$ did not have diseases that could affect fertility, moreover, they have normal findings on physical examination, as well as endocrine, genetic and biochemical laboratory tests, i.e. there is no male factor to explain the pathological finding of semen. For these patients we can use the term idiopathic male infertility. In most cases, patients or couples (which is considered a better option) are referred to a urologist or andrology subspecialist when an abnormal semen analysis is found at the gynecologist. A detailed medical history and physical examination are usually the first step, followed by at least two semen analysis, determination of hormone levels (Follicle-stimulating hormone (FSH), luteinizing hormone ( $\mathrm{LH})$, testosterone, prolactin, estradiol, thyroid stimulating hormone (TSH), thyroxine (T4), sex hormone binding globuine (SHBG)), urine and semen bacterial testing, testicular ultrasound and genetic analysis (karyotype, Y chromosome microdeletion and cystic fibrosis). Sometimes further testing based on these findings is needed ${ }^{5}$ Various techniques can be used in patients diagnosed with azoospermia, such as percutaneous sperm aspiration (PESA), microsurgical epididymal sperm aspiration (MESA), testicular sperm aspiration (TESA), testicular sperm extraction (TESE) and microsurgical testicular sperm extraction (mTESE). The best sperm retrieval rate is achieved by TESE and mTESE techniques, and the most common histological finding in these patients is "mixed atrophy", the presence of normal seminiferous tubules mixed with atrophic tubules.

\section{COnVEntional TESE PROCEDURE}

Conventional TESE is usually performed as an outpatient procedure. After the preparation of the operative field and local anesthesia, an incision of the skin and subcutaneous tissue and exposure of the testis is performed, followed by the incision of tunica albuginea on three different parts (upper, middle and lower) to increase the possibility of positive sperm findings according to the European Academy of Urology (Figure 1). Patients are discharged from the hospital the same afternoon. They should rest for a few days, and a full recovery is expected in 14 days. Immediately after harvesting testicular tissue, embryologist begins microdissection of tissue under sterile conditions in laminar flow (Figure 2). Each piece of tissue is divided into two parts. The first part is immersed in cryo-medium as a preparation for the deep-freezing procedure, and the second part is prepared for a detailed pathohistological examination. The deep-freezing tissue is programmably frozen and stored in a container with liquid nitrogen. Tissue for pathohistological analysis (PHA) is fixed and stained with hematoxylin eosin and immunohistochemically (IHC), then a detailed pathohistological analysis is performed. PHA was scored using the Johnsen International Scoring System to analyze the degree of preservation of spermatogenesis, from $0-10$. Zero is the worst value and means that only fibrotic tissue was found, and ten is the best value and means full spermatogenesis. The higher the score the greater the chance of successful intracytoplasmic sperm injection/in vitro fertilisation (ICSI/IVF) procedures, ideally a score of nine and ten is the best (Table 1) ${ }^{24}$. To avoid unexpected genetic abnormalities, only sperm should be used in the ICSI/IVF procedure, not spermatids. Immunohistochemical staining is very important because in these patients the probability of germ cell neoplasia in situ (GCNIS) is one hundred times higher.

\section{MTESE PROCEDURE}

Microsurgical testicular sperm extraction (mTESE) was first described by Schlegel in $1999^{6}$ as an advanced microsurgical treatment assisted with operating microscope for retrieving sperm from men with NOA. ${ }^{7}$ Some recent studies suggests that mTESE is 1.5-fold better at sperm extraction than conventional TESE when harvesting random multiple biopsies at three different parts of the testis. It is also twice as effective as testicular aspiration (TESA) in controlled trials. ${ }^{8}$ Spermatogenesis does not show homogeneity in all parts of the testis, moreover, most seminiferous tubules in NOA do not show normal stratification and germ cells count, but only small, thin tubules that do not contain sperms or any form of normal spermatogenesis. However, under 20-25-fold microscopic magnification with precise microdissection, seminal tubules with full spermatogenesis are more easily identified. These tubules are larger and most opaque on microscopic appearance and are therefore different from the surrounding tubules. Using an inverted microscope they can be promptly analysed for the presence of sperm. This led to the identification of sperm in $63 \%$ of men using the mTESE technique, compared to $45 \%$ of sperm retrieval using the conventional TESE technique in the original publication. However, both methods have advanced over the years and numerous studies have been made that compare them. Corona et al i 2019. performed a systematic review and meta-analysis and found no differences when mTESE was compared with conventional TESE (46[43;49]\% for TESE versus 46[42;49]\% for mTESE) 
and in general we can say that they are similar with a sperm retrieval rate around 50\%. ${ }^{9}$

There is always a question which method is better for which patients, i.e. which patients can benefit from mTESE procedure? Many factors such as the patient's age, hormone levels, testicular volume, and previous surgical procedures influence the choice of procedure. If TESE did not result in a satisfactory sperm retrieval rate, we can try the mTESE, but even mTESE cannot retrieve sperm in patients with severely damaged testicles like patients with Klinefelter syndrome. To clarify which technique is superior, we need a sufficiently strong and well-designed prospective, multicentric and randomized controlled study to compare mTESE to TESE in men with NOA.

Some patients have a combination of varicocele and azoospermia and the question is whether they can benefit from varicocelectomy (VR). Esteves et al. performed a meta-analysis evaluating the role of VR in men with NOA and concluded that VR may be associated with sperm appearance in the postoperative ejaculate and may affect surgical sperm retrieval rate. ${ }^{10}$ However, there are biases in many of the studies analyzed, moreover, the results of varicocele repair can be observed only after 3-6 months. 11 Also, some results suggest that $10-18 \%$ of men with NOA will have sperms in ejaculate with control semen analysis without any surgical intervention for varicocele. Many patients have female partners in their late thirties or early forties and do not want any prolongation of a possible child conceiving and choose immedi- ate sperm retrieval technique without waiting for possible sperm recovery after VR. 12-22

Almost all patients with NOA have abnormal sex hormone findings. In most of them, FSH levels are high, while LH levels and testosterone levels are normal, but for those with lower testosterone levels, adjuvant hormone therapy may be helpful. Hussein et al. in a prospective, multicentric study in 42 patients with NOA and a histopathological diagnosis of maturation arrest or hypospermatogenesis, used clomiphene citrate for 3-9 months at a dose of $25 \mathrm{mg} / \mathrm{d}$ to $75 \mathrm{mg} / \mathrm{d}$. Semen analyses showed that in $64.3 \%$ of men the sperm concentration increased to an average of 3.8 million $/ \mathrm{mL} .{ }^{23}$ In addition to clomiphene citrate, aromatase inhibitors can be used, depending on the testosterone/estradiol (T:E2) ratio. For example, if T:E2 was $<10,1 \mathrm{mg}$ of anastrozole daily is advised. For men with an inadequate testosterone response, added injections of human chorionic gonadotropin (hCG) at a dose of 1,500 IU subcutaneously two or three times a week may be given. Depending on the pathohistological findings during previous conventional TESE procedure, some patients might benefit from 150 IU human recombinant follicle stimulating hormone $(\mathrm{rFSH})$ substitution two or three times a week for several months before a new mTESE procedure is performed, especially if FSH levels are normal and PHE result suggests spermatide stop. However, recently published papers have shown conflicting results, namely a failure of the sperm retrieval rate ${ }^{3}$. Therefore, care should be taken when deciding which therapy should be given to the patient.

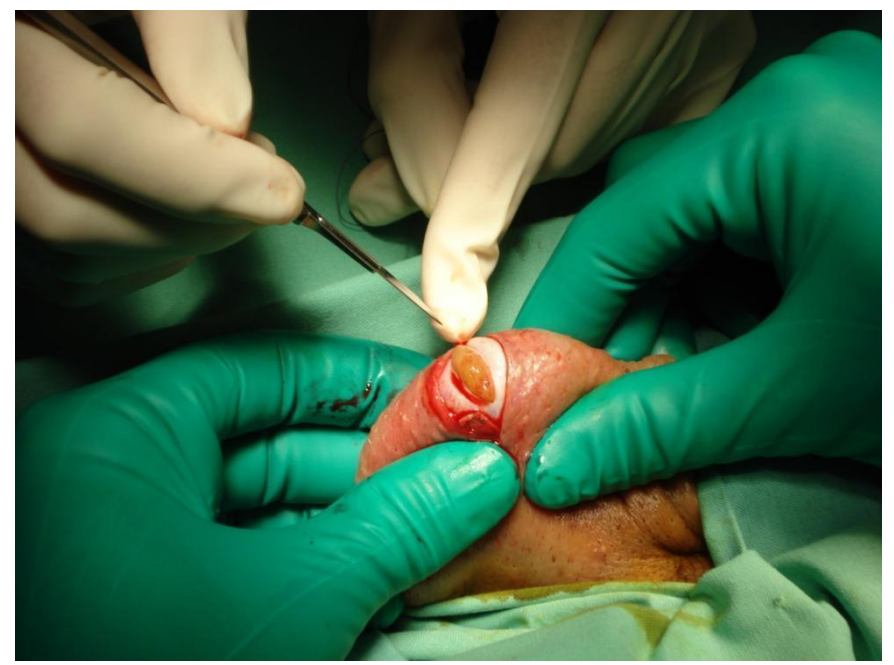

Figure 1. "Open" testicular biopsy. The assistant holds the testicle in a fixed position while the operator uses a scalpel to approach the parenchyma of the testis, which gently protrudes through the incision of the tunica albuginea.

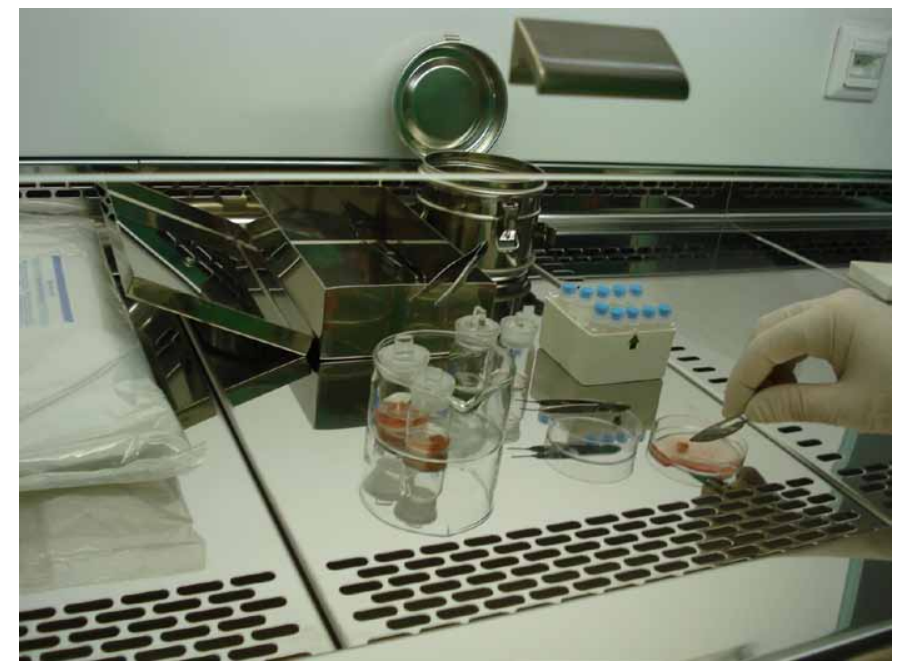

Figure 2. Shows tissue microdissection in laminar flow. 


\begin{tabular}{|l|l|}
\hline Score & Histological criteria \\
\hline 10 & Full spermatogenesis \\
\hline 9 & Slightly impaired spermatogenesis, many late spermatids, disorganized epithelium \\
\hline 8 & Less than five spermatozoa per tubule, few late spermatids \\
\hline 7 & No spermatozoa, no late spermatids, many early spermatids \\
\hline 6 & No spermatozoa, no late spermatids, few early spermatids \\
\hline 5 & No spermatozoa or spermatids, many spermatocytes \\
\hline 4 & No spermatozoa or spermatids, few spermatocytes \\
\hline 3 & Spermatogonia only \\
\hline 2 & No germinal cells, Sertoli cells only \\
\hline 1 & No seminiferous epithelium \\
\hline
\end{tabular}

Table 2. Our results showing number of spermatozoa and spermatids in all and NOA patients.

\begin{tabular}{|l|l|l|}
\hline & NOA & All (NOA+OA) \\
\hline No patients & $302(90 \%)$ & 336 \\
\hline Spermatozoa & $163(54 \%)$ & $198(59 \%)$ \\
\hline Late spermatids & $39(13 \%)$ & $37(11 \%)$ \\
\hline
\end{tabular}

\section{OUR EXPERIENCE}

At the University Hospital Centre Zagreb, we have established the Centre for reproductive medicine and andrology in 2015, which unites many departments (mainly urology and gynaecology) that help infertile couples. Our centre is accredited by the European Academy of Andrology. We started the TESE procedure in 2013, and so far in 9 years we have performed a total of 336 procedures in collaboration with School of Medicine Zagreb, Department for histology and embryology. All harvested testicular tissue is stored in liquid nitrogen in the Department for tissue banking. We had $90 \%$ of patients with NAO and $10 \%$ with OA, with a sperm retrieval success rate of $59 \%$, which is comparable with well recognised infertility world centres. When we analysed patients with NOA, we found sperms in 54\% of patients and late spermatids in $13 \%$ of patients (Table 2). These good sperm retrieval rates are achieved by using multiple incisions on each testis. Complications are rare and we observed only three scrotal haematomas and four wound infections.

There are patients with a previous failure of sperm retrieval during
TESE procedure, and also patients with genetic disorders such as Klinefelter syndrome who could benefit from mTESE procedure. This demanding and time-consuming technique should be offered to carefully selected patients. With this technique less tissue will be harvested for best results. We are still not performing this procedure, but we are planning to do it in the near future.

\section{CONLUSION}

Male infertility is becoming an increasing demographic problem. Sperm retrieval techniques are the only possibility for biological child conceiving in patients with diagnosed azoospermia. In more than half of our patients, we found sperm that could be used in the combined ICSI / IVF procedure, which could enable them to become biological fathers/parents, and which would have been impossible without this technique. For highly selected patients in whom TESE has failed, we can offer more advanced sperm finding techniques such as mTESE. Further research and advances in a very important area of tissue culture are likely to help even more azoospermic patients in the future. 


\section{REFERENCES:}

1. Donoso P, Tournaye H, and Devroey P. Which is the best sperm retrieval technique for non-obstructive azoospermia? A systematic review. Hum Reprod Update. 2007;13:539549.

2. Söderström KO. Leydig cell hyperplasia. Arch Androl. 1986;17(1):57-65.

3. Agarwal, A., et al. Male Oxidative Stress Infertility (MOSI): Proposed Terminology and Clinical Practice Guidelines for Management of Idiopathic Male Infertility. World J Mens Health, 2019. 37: 296.

4. Jonathan Fainberg, James A Kashanian. Recent advances in understanding and managing male infertility. F1000Res 2019 May 16;8:F1000 Faculty Rev-670. doi: 10.12688/f1000research.17076.1.

5. Salonia A et al. EAU guidelines on sexual and reproductive health. European association of urology 2020.

6. Schlegel PN. Testicular sperm extraction: microdissection improves sperm yield with minimal tissue excision. Hum Reprod 1999;14:131-5.

7. Flannigan RK, Schlegel PN. Microdissection testicular sperm extraction: preoperative patient optimization, surgical technique, and tissue processing. Fertil Steril. 2019 Mar;111(3):420-426. doi: 10.1016/j.fertnstert.2019.01.003

8. Bernie AM, Mata DA, Ramasamy R, Schlegel PN. Comparison of microdissection testicular sperm extraction, conventional testicular sperm extraction, and testicular sperm aspiration for nonobstructive azoospermia: a systematic review and meta-analysis. Fertil Steril 2015;104: 1099-103.e1-3.

9. Corona $\mathrm{G}$ et al. Sperm recovery and ICSI outcomes in men with non-obstructive azoospermia: a systematic review and meta-analysis. Hum Reprod Update. 2019 Nov 5;25(6):733-757. doi: 10.1093/humupd/dmz028.

10. Esteves SC, Glina S. Recovery of spermatogenesis after microsurgical subinguinal varicocele repair in azoospermic men based on testicular histology. Int Braz J Urol 2005;31:5418.

11. Matthews GJ, Matthews ED, Goldstein M. Induction of spermatogenesis and achievement of pregnancy after microsurgical varicocelectomy in men with azoospermia and severe oligoasthenospermia. Fertil Steril 1998;70: 71-5.

12. Kim ED, Leibman BB, Grinblat DM, Lipshultz LI. Varicocele repair improves semen parameters in azoospermic men with spermatogenic failure. J Urol 1999;162(3 Pt 1):737-40.
13. KadiogluA, TefekliA,CayanS,Kandirali E,Erdemir F,Tellaloglu S.Microsurgical inguinal varicocele repair in azoospermic men. Urology 2001;57:328-33.

14. Cakan M, Altug U. Induction of spermatogenesis by inguinal varicocele repair in azoospermic men. Arch Androl 2004;50:145-50.

15. Pasqualotto FF, Sobreiro BP, Hallak J, Pasqualotto EB, Lucon AM. Induction of spermatogenesis in azoospermic men after varicocelectomy repair: an update. Fertil Steril 2006;85:635-9.

16. Lee JS, Park HJ, Seo JT. What is the indication of varicocelectomy in men with nonobstructive azoospermia? Urology 2007;69:352-5.

17. Cocuzza M, Pagani R, Lopes RI, Athayde KS, Lucon AM, Srougi M, et al. Use of subinguinal incision for microsurgical testicular biopsy during varicocelectomy in men with nonobstructive azoospermia. Fertil Steril 2009; 91:925-8.

18. Abdel-Meguid TA. Predictors of sperm recovery and azoospermia relapse in men with nonobstructive azoospermia after varicocele repair. J Urol 2012; 187:222-6.

19. Kirac M, Deniz N, Biri H. The effect of microsurgical varicocelectomy on semen parameters in men with nonobstructive azoospermia. Curr Urol 2013;6:136-40.

20. Zampieri N, Bosaro L, Costantini C, Zaffagnini S, Zampieri G. Relationship between testicular sperm extraction and varicocelectomy in patients with varicocele and nonobstructive azoospermia. Urology 2013;82:74-7.

21. Aboutaleb HA, Elsherif EA, Omar MK, Abdelbaky TM. Testicular biopsy histopathology as an indicator of successful restoration of spermatogenesis after varicocelectomy in nonobstructive azoospermia. World J Mens Health 2014;32:43-9.

22. Inci K, Hascicek M, Kara O, Dikmen AV, Gurgan T, Ergen A. Sperm retrieval and intracytoplasmic sperm injection in men with nonobstructive azoospermia, and treated and untreated varicocele. J Urol 2009;182:1500-5.

23. Hussein A, Ozgok Y, Ross L, Niederberger C. Clomiphene administration for cases of nonobstructive azoospermia: a multicenter study. J Androl 2005;26: 787-91; discussion 792-793.

24. Kobyliak et al. Antioxidative effects of cerium dioxide nanoparticles ameliorate age-related male infertility: optimistic results in rats and the review of clinical clues for integrative concept of men health and fertility. The EPMA Journal (2015) 6:12 
